Bessel functions to the habits of lizards seems very little known, and much time has in consequence been wasted by research workers in collecting information on subjects in which bibliographies were already in existence.

\section{Street Lighting}

Illuminating engineers are beginning to agitate for national control of the lighting of roads and streets. In the Electrical Review of June 8, C. W. Sully points out that boroughs and urban councils in Great Britain are granted powers regarding street lighting by the Public Health Act of 1875 and that rural districts exercise their powers under the Lighting and Watching Act of 1833. The public lighting of all our thoroughfares to-day is controlled by Acts published either sixty or a hundred years ago. Our population has nearly trebled since 1833 and has increased by more than seventy per cent since the last Act became law. There were no fast moving vehicles on our roads sixty years ago-there are now two million licensed automobiles. The existence of vast numbers of cinemas and also of greyhound racing tracks encourages pedestrians to use the streets after dark. Yet much of our highway lighting is mounted on similar posts spaced at the same distance apart as when our road vehicles were fitted with lanterns carrying candles. The candle power of the lights have been increased a hundred-fold in order to lessen the risk of accidents but in many roads the lighting is very 'patchy', the lamps acting mainly as beacon lights. It is wasteful to employ large units without suitable directive fittings to ensure a uniform distribution of the light. The new British Standard Specification makes a special feature of this by setting out a spacing ratio for street lights which produces a more uniform illumination. In general this entails altering the height of the posts. It would be advisable if the Government would allot to one of its numerous departments the task of specifying the minimum light to be provided on the various roads which it has already classified. It appears that new legislation is required to deal with this important matter.

\section{Some Aspects of the Vertebrate Brain}

In his presidential address before the Linnean Society of New South Wales on March 28, Prof. A. N. Burkitt outlined progress in our knowledge of the structure and workings of the brain. The present lopsidedness of our knowledge, so amazing in the physical and chemical world and so backward as regards the very instrument which has created human civilisation, is the cause of much of the discontent and difficulties of our present age. Recent work upon the sense organs and the impulses they transmit to the brain, and some idea of how closely parallel to the physical reality these impulses may be, was discussed, partly in relation to philosophical problems. The bearing of the evolution of the sense organs upon the evolution of the brain, so ably outlined by Elliot Smith, was briefly mentioned. The importance of the recent discovery that the emotional aspect of life is associated with the activity of a special part of the brain, the thalamus, distinct and separate from the great thinking and discriminatory apparatus, the cerebral cortex, was emphasised, and suggestions were made as to the possible bearing of this knowledge upon the Freudian hypothesis. Finally, an attempt was made to suggest some inkling of the physiological phenomena that occur in the brain during conscious thinking in all its myriad aspects ; also the mechanisms concerned in expression and the control of muscles, together with the evolution of these controlling mechanisms and muscles, were briefly outlined.

\section{Organisation of Production}

UNDER the title "Prohibiting Poverty", a pamphlet by P. M. Martin, written and published by P. M. Martin, Winter Park, Florida, outlines a plan for obtaining economic security, based on the view that the prime purpose of organised society is to enable everyone to get a living. The plan, described as the "National Livelihood Plan", proposes to separate necessaries from luxuries, and to deal with them in separate departments of govern. ment on different principles. The production of necessities is to be organised under a new national organisation, known as the Commons, the function of which is to produce and distribute a basic livelihood in necessities to the entire population. This organisation would operate without money, distributing goods as produced without selling them. It would be recruited compulsorily by the whole youth of the nation from school-leaving age and would utilise the full advantages of scientific discovery in increasing industrial output and efficiency. After eight years' service, the Commoner would pass into the Capitals, in which the existing capitalistic organisation of society would persist, limited, however, to the production of luxuries, and in which his previous labours have earned him or her a free distribution for life from the Commons of the basic necessities of life. The Commons would be directed by a salaried body of technical experts, men of science and investigators concerned with the continual development and full utilisation of improved methods of production.

\section{Animal Breeding in the British Empire}

THE Imperial Bureau of Animal Genetics has issued a bulletin of 47 pages by Dr. F. Fraser Darling on animal breeding in the British Empire, obtainable from Oliver and Boyd, Edinburgh, or 33 Paternoster Row, E.C., at 1s. It summarises the present position and work in progress in the breeding of farm animals in all parts of the Empire. The first part deals with Great Britain and the Dominions, where conditions are mainly temperate; the second part with India and the Colonies, which are largely in the tropics. The more practical aspects of the breeding of horses, cattle, sheep, pigs and goats are considered. Reference is made to such recent developments as sperm storage for horse insemination, and the fact that breeds of pigs differ in the number of ribs and hence 